\title{
Avaliação Microbiológica e Sensorial de Geleias de Amora-Preta
}

Mônica Turchetto (I), Endy Camile de Noronha (I), Débora Turchetto Zamban (I), Giovana Paula Zandoná (I), Josiane Souza Santos (I), Bruna Martins Parodes (I), Renato Trevisan (I), Magda Aita Monego (I), Ana Eucares Von Laer (I), Valéria Maria Limberger Bayer (I)

(I) UFSM - Universidade Federal de Santa Maria (Linha Sete de Setembro, s/n, CEP: 98400000, Frederico Westphalen, RS, Brasil)

\section{Resumo}

Da colheita à mesa do consumidor, há um grande desperdício de frutas e hortaliças, cerca de até $40 \%$, em razão da produção sazonal, da elevada perecibilidade e rápida perda de qualidade pós-colheita, além do possível desconhecimento de como aproveitar melhor a produção. Assim, uma alternativa para o aproveitamento de frutas que não são consumidas in natura é empregá-las como matéria-prima no processamento de derivados, que além do aproveitamento, agrega valor aos produtos e pode incrementa a renda dos fruticultores. Deste modo, o emprego de amora-preta na elaboração de polpas e geleias, além de constituir uma excelente alternativa de aproveitamento do excedente de produção, pode gerar produtos com características sensoriais agradáveis e nutricionais satisfatórias. Sendo assim, o objetivo do presente trabalho foi testar diferentes formulações de geleias de amora-preta, avaliar sua estabilidade microbiológica, bem como verificar sua aceitabilidade e intenção de compra frente aos consumidores. Foram elaboradas quatro formulações diferentes de geleia de amora-preta: GA com $40 \%$ polpa e $50 \%$ açúcar, GB com $50 \%$ polpa e $50 \%$ açúcar, GC com $40 \%$ suco e $60 \%$ açúcar e GD com $50 \%$ suco e $50 \%$ açúcar. Foram realizadas análises quanto à contagem de bolores e leveduras e aplicados os testes de aceitabilidade com escala hedônica e atitude de compra. Os resultados obtidos foram submetidos ao Teste de Tukey a 5\% de

\footnotetext{
Referência:

Mônica Turchetto, Endy Camile de Noronha, Débora Turchetto Zamban, Giovana Paula Zandoná, Josiane Souza Santos, Bruna Martins Parodes, Renato Trevisan, Magda Aita Monego, Ana Eucares Von Laer, Valéria Maria Limberger Bayer. Avaliação Microbiológica e Sensorial de Geleias de Amora-Preta. In: Anais do 12을 Congresso Latinoamericano de Microbiologia e Higiene de Alimentos - MICROAL 2014 [= Blucher Food Science Proceedings, num.1, vol.1]. São Paulo: Editora Blucher, 2014. DOI 10.5151/foodsci-microal-139
} 
significância $(\mathrm{p} 0,05)$ entre as amostras com relação às análises microbiológicas e sensoriais. O emprego da amora-preta na elaboração de geleias, mantendo-se as Boas Práticas de Fabricação (BPF), propicia produtos microbiologicamente seguros e com características sensoriais agradáveis e boa aceitabilidade, além de constituir uma excelente alternativa de aproveitamento do excedente de produção.

Palavras-Chave: Rubus spp, bolores e leveduras , aceitabilidade Agência de Fomento: 